\title{
New Perspectives on the Use of Cannabis in the Treatment of Psychiatric Disorders
}

\author{
Maria Scherma ${ }^{1}(1)$, Paolo Masia ${ }^{1}$, Matteo Deidda ${ }^{1}$, Walter Fratta ${ }^{1}$, Gianluigi Tanda ${ }^{2}$ \\ and Paola Fadda 1,3,4,5,* \\ 1 Department of Biomedical Sciences, Division of Neuroscience and Clinical Pharmacology, \\ University of Cagliari, 09042 Monserrato, Italy; mscherma@unica.it (M.S.); paolo.masia@unica.it (P.M.); \\ matteo.deidda@unica.it (M.D.); wfratta@unica.it (W.F.) \\ 2 Medication Development program, NIDA-IRP, NIH/DHHS, NIDA suite 3301, Baltimore, MD 21224, USA; \\ gtanda@intra.nida.nih.gov \\ 3 Centre of Excellence "Neurobiology of Dependence", University of Cagliari, 09042 Monserrato, Italy \\ 4 CNR Institute of Neuroscience - Cagliari, National Research Council, 09042 Monserrato, Italy \\ 5 National Institute of Neuroscience (INN), University of Cagliari, 09042 Monserrato, Italy \\ * Correspondence: pfadda@unica.it
}

Received: 7 August 2018; Accepted: 30 September 2018; Published: 2 October 2018

\begin{abstract}
Following the discovery of the endocannabinoid system and its potential as a therapeutic target for various pathological conditions, growing interest led researchers to investigate the role of cannabis and its derivatives for medical purposes. The compounds $\Delta 9$-tetrahydrocannabinol and cannabidiol are the most abundant phytocannabinoids found in cannabis extracts, as well as the most studied. The present review aims to provide an overview of the current evidence for their beneficial effects in treating psychiatric disorders, including schizophrenia, anxiety, and depression. Nevertheless, further investigations are required to clarify many pending issues, especially those relative to the assessment of benefits and risks when using cannabis for therapeutic purposes, thereby also helping national and federal jurisdictions to remain updated.
\end{abstract}

Keywords: phytocannabinoids; $\Delta$ 9-tetrahydrocannabinol; cannabidiol; psychiatric disorders

\section{Introduction}

Evidence of the consumption of cannabis for therapeutic uses is prevalent throughout history. The first indication of use dates back to 2700 before Christ (BC), in the world's oldest Chinese pharmacopeia, the Pen-ts'ao ching, which recommended cannabis for the treatment of constipation, malaria, gout, rheumatism, and painful menstruation, among others [1]. Around the year 1000 BC, the presence of cannabis was widespread throughout India, where its medical uses were numerous, owing to its analgesic, anti-inflammatory, anticonvulsant, appetite-stimulant, tranquilizing, and diuretic properties [2]. Subsequently, the plant gradually spread across the world. Cannabis use in Western medicine dates back to the first half of the 19th century, when Irish physician William Brooke O'Shaughnessy recommended it for a great variety of therapeutic purposes, including muscle spasms, menstrual cramps, and rheumatism, as well as convulsions of tetanus, rabies, and epilepsy [3]. Moreover, French psychiatrist Jean-Jacques Moreau de Tours experimented with the therapeutic use of cannabis in mental disorders, and described the plant as hypnotic, analgesic, and anticonvulsant [4]. In the second half of the 19th century, over 100 scientific articles were published regarding the therapeutic value of the plant, and cannabis extracts were listed for sedative and anticonvulsant effects in the British, and later United States (US), pharmacopeia [5]. However, the first few decades of the 20th century were characterized by decreased attention to the medical use of cannabis due 
to the social impact of increased drug consumption for recreational purposes, as well as to the fact that the effects were difficult to predict and standardize because of the variable composition of plant extracts. In the following years, cases of the medical use of cannabis completely subsided until the first decades of the 21st century, during which it returned to being considered for therapeutic purposes, despite its use being highly restricted [2]. The cannabis plant contains a total of 483 compounds, among which more than 120 are bioactive constituents, collectively known as phytocannabinoids [6]. Among them, the most important and studied are $\Delta$ 9-tetrahydricannabinol $(\triangle 9-\mathrm{THC})$ and cannabidiol (CBD), which also represent the major constituents found in the plant. CBD was first isolated in 1940, but it was not until 1963 that its structure was clarified $[7,8]$. On the other hand, $\triangle 9-T H C$ was isolated in 1964, and was soon thereafter synthesized and found to be the primary psychoactive constituent of cannabis $[9,10]$. Primarily, the pharmacological effects of cannabis were attributed to the ability of $\triangle 9$-THC to alter specific membrane properties due to its high lipophilicity [11]. Nevertheless, evidence of it being able to inhibit the formation of adenylate cyclase [12] instigated researchers to hypothesize on the existence of a specific receptor for this compound. This receptor, named CB1 (CB1R), was cloned for the first time, in 1990, from a rat cerebral-cortex complementary DNA (cDNA) library [13], and it represents the most abundant G-protein-coupled receptor in the brain [14]. Later on, a second cannabinoid receptor, named CB2 (CB2R), derived from human promyelocytic leukemic cells (HL-60 cells), was cloned [15]. CB2R also belongs to the family of G-protein-coupled receptors, and it is mainly expressed in the immune system, while also being identified in some areas of the brain [16]. Recent studies suggest the existence of other cannabinoid receptors, including the orphan G-protein-coupled receptor, GPR55 [17]. Moreover, a growing body of evidence identified other receptors as cannabinoid targets, including the type 1 vanilloid receptor (TRPV1) and peroxisome proliferator-activated receptor [18]. The discovery of cannabinoid receptors prompted researchers to find endogenous ligands that activate them. The first endocannabinoid to be isolated, in 1992, was anandamide (AEA) [19]. Three years later, 2-arachidonoylglycerol (2-AG) became the second endocannabinoid to be identified [20]. In addition to AEA and 2-AG, several other compounds with endocannabinoid-like activity were isolated, including 2-arachidonylglyceryl ether (2-AGE, noladin), $\mathrm{O}$-arachidonylethanolamine (virodhamine), and $\mathrm{N}$-arachidonyldopamine (NADA) [21]. Soon after, the biochemical processes responsible for endocannabinoid synthesis and degradation were also identified [22]. AEA and 2-AG are synthesized upon demand in $\mathrm{Ca}^{2+}$-dependent manner after cellular depolarization from lipid precursors, which are components of the cell membrane. AEA is derived mainly from the cleavage of $N$-arachidonoylphosphatidylethanolamine (NAPE), which is then specifically hydrolyzed by phospholipase D (NAPE-PLD); 2-AG is primarily formed from the hydrolysis of 1,2-diacylglycerol (DAG) by the phospholipase C/diacylglycerol lipase pathway [23]. Once synthesized, AEA and 2-AG are immediately released by the postsynaptic terminal and activate cannabinoid receptors (CBRs) in the presynaptic membrane, inhibiting neurotransmission release by activating presynaptic $\mathrm{K}^{+}$channels and inhibiting $\mathrm{N}$ - and P/Q-type $\mathrm{Ca}^{2+}$ channels [23]. Endocannabinoid signaling is terminated by rapid metabolic deactivation via specific enzymes after being taken up into the cell. AEA is primarily metabolized by the intracellular enzyme, fatty-acid amide hydrolase (FAAH), which breaks it down into free arachidonic acid. Ethanolamine, as well as the pharmacological blockade and genetic deletion of this enzyme, not only enhances AEA levels, but also amplifies its effects [24,25]. The compound 2-AG is metabolized into arachidonic acid and glycerol mainly by the enzyme monoacylglycerol lipase (MAGL) [23]. These metabolic pathways represent the key points in the regulation of endocannabinoid tissue levels. Altogether, these elements are part of the endocannabinoid system representing important lipid signaling, which was recently recognized as a modulator of a large variety of physiological processes, as well as of emotional responses and cognitive function [26] (Figure 1). Abnormalities in emotion and cognitive deficits are characteristic of several neuropsychiatric conditions; thus, a defect in endocannabinoid signaling might play a role in the pathophysiology of these disorders $[27,28]$. The present review addresses the current literature on the endocannabinoid system in the neurobiology of psychiatric disorders, 
specifically schizophrenia and mood disorders (anxiety and depression), and current evidence for the beneficial effects of phytocannabinoids in treating them.

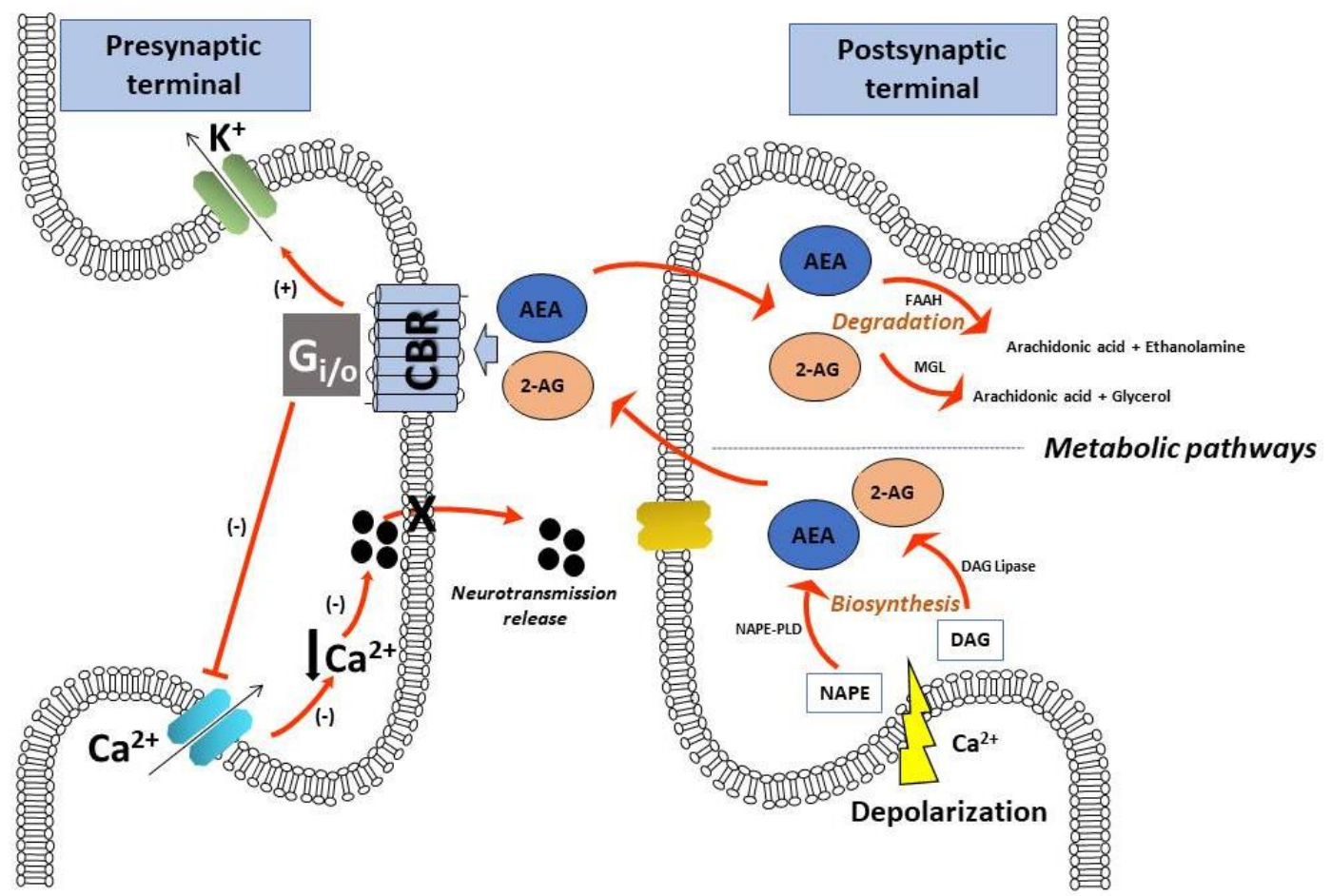

Figure 1. Schematic representation of the main elements of the endocannabinoid system at the synaptic level: endocannabinoids are produced upon demand after cellular depolarization from lipid precursors. AEA is derived mainly from NAPE by a specific phospholipase D; 2-AG is primarily formed from the hydrolysis of DAG. Once released from postsynaptic terminal, AEA and 2-AG activate CBRs in the presynaptic terminal, inhibiting neurotransmission release by activating presynaptic $\mathrm{K}^{+}$channels and inhibiting $\mathrm{Ca}^{2+}$ channels. Endocannabinoid signaling is terminated by metabolic degradation by specific enzymes. AEA: anandamide; 2-AG: 2-arachidonoylglycerol; FAAH: fatty acid amide hydrolase; MGL: monoacylglycerol lipase; DAG: diacylglycerol; NAPE: N-acyl-phosphatidylethanolamine; NAPE-PLD: $N$-acyl-phosphatidylethanolamine phospholipase D; CBR: cannabinoid receptor; Gi/o: G protein; $\mathrm{Ca}^{2+}$ : calcium; $\mathrm{K}^{+}$: potassium.

\section{Search Methods}

A PubMed database search was performed using the combination of keywords: "Cannabis", "phytocannabinoids", " $\Delta$ 9-tetrahydrocannabinol", "cannabidiol", "endocannabinoid system", "psychiatric disorders", "psychosis", "Schizophrenia", "anxiety disorders", and "depression". The search was carried out considering both human and animal studies articles. Clinical trials in healthy subjects were also considered.

\section{Therapeutic Potential of Cannabis Extracts on Psychiatric Disorders}

\subsection{Schizophrenia}

Schizophrenia (SCZ) is a severe psychiatric disorder whose clinical features fall into three categories: positive symptoms that include hallucinations, delusions, disorganized speech, and catatonia; negative symptoms indicating disruption in the expression of emotions or difficulty in beginning and sustaining activities (e.g., depression, anhedonia, and blunted affection); and cognitive deficits in working and verbal memory, as well as in executive function and attention [29]. The more severe the negative symptoms and cognitive deficits are, the more marked the disability is [30]. SCZ affects around $0.5-1 \%$ of the population worldwide and tends to be chronic, with a substantial impact 
on quality of life [31]. Antipsychotic medications, which represent the main treatment for SCZ, reduce psychotic symptoms, but are not effective in all patients: $30-60 \%$ of them are refractory to all current treatments. Moreover, these drugs cause several adverse effects $[32,33]$. Thus, the discovery of new molecular targets for the development of novel medication is of critical importance. In the last few years, a cannabinoid hypothesis of SCZ was postulated, and the pharmacological modulation of the endocannabinoid system could be considered a potential therapeutic tool for SCZ treatment [34].

\subsubsection{Human Studies}

Clinical studies showed altered endocannabinoid signaling in schizophrenic patients [35]. For instance, elevated levels of AEA were found in the blood and cerebrospinal fluid of schizophrenic patients that were normalized by antipsychotic treatment [36-39]. Furthermore, increased cerebrospinal fluid levels of AEA seem to be negatively correlated with psychotic symptoms, and this increase may represent a protective role against psychosis [38]. Altered CB1R densities in schizophrenic patients were also reported, even though results were not entirely consistent across studies. Accordingly, an increase [40-42], decrease [43,44], or even lack of alteration [45] in CB1R density was found in cortical regions that are thought to be linked to SCZ, such as the dorsolateral prefrontal cortex and the anterior cingulate cortex. Since CB1R changes were investigated using radioligand binding and quantitative autoradiography in postmortem tissue, the variation in techniques used could account for the discrepancies obtained in these studies. Moreover, inconsistent results may also be related to the use of antipsychotic treatment [46] or cannabis consumption [40]. On the other hand, in vivo brain-imaging techniques in schizophrenic patients reported elevated CB1R binding in the pons, nucleus accumbens, cingulate, and insular cortex [47-49]. Recent clinical evidence also supports a role for CB2R. Indeed, reduced expression of CB2R was found in peripheral blood mononuclear cells of untreated schizophrenic patients with first-episode psychosis [50], as well as in patients following treatment with olanzapine [37]. Finally, genetic polymorphisms in the CB1R gene (CN1R) were implicated in susceptibility to SCZ; however, other studies showed no association [51-54]. Moreover, a correlation between single-nucleotide polymorphisms in the CB2R gene (CNR2) and increased risk of SCZ were reported [51]. In addition to an alteration of the endocannabinoid system, epidemiological evidence suggests that cannabis use is linked to an increased risk of developing SCZ in genetically predisposed people, as well as to precipitate psychotic symptoms in schizophrenic patients [55]. Early onset of use greatly increases the risk: meta-analysis studies indicated that adolescent cannabis use may account for $8-14 \%$ of SCZ cases $[55,56]$. On the other hand, the high rate of cannabis use in several schizophrenic patients was interpreted as an attempt to self-medicate negative symptoms or to overcome the feeling of depression and anxiety associated with these symptoms [57]. As mentioned earlier, $\triangle 9$-THC is the main psychoactive component of cannabis, and it is the active ingredient responsible for psychotic outcomes. Indeed, acute $\triangle 9$-THC administration elicits both positive and negative symptoms, as well as cognitive deficits in healthy individuals, while also inducing a transient exacerbation in psychotic symptoms and cognitive deficits in schizophrenic patients $[58,59]$. Neuroimaging studies showed that $\triangle 9$-THC-induced psychotic symptoms are associated with the altered activity of several brain areas affected by SCZ, including the prefrontal cortex ( $\mathrm{PFC}$ ), anterior cingulate cortex, amygdala, and ventral striatum $[60,61]$. By contrast, despite the lack of evidence supporting $\triangle 9$-THC-based medical treatments for SCZ, a recent study reported that three out of six treatment-resistant patients improved their schizophrenic symptoms following treatment with the synthetic form of $\triangle 9$-THC (dronabinol) [62]. Unlike $\triangle 9$-THC, CBD represents the most abundant non-psychoactive component of cannabis; it shows low CBR binding and partly antagonizes the actions of $\triangle 9$-THC and other synthetic CB1R agonists like WIN-55212 and CP-55940 [63]. Moreover, CBD inhibits AEA hydrolysis, stimulates vanilloid receptors like TRPV1, activates 5-HT1A receptors, and also exerts partial agonist activity on dopamine D2 receptors [64,65]. Recently, CBD received growing attention for its antipsychotic properties; thus, it could be considered a promising new agent in the treatment of SCZ $[66,67]$. Firstly, in healthy subjects, CBD blocked the psychotic symptoms 
induced by $\triangle 9$-THC [68]. Moreover, randomized clinical trials (RCTs) evaluating the clinical efficacy of $\mathrm{CBD}$ in psychosis found that it was able to improve both positive and negative symptoms in schizophrenic patients [32,69-71]. Furthermore, the clinical efficacy of CBD was comparable with that of amisulpride, but with fewer side effects [72]. Although the mechanism through which CBD exerts its antipsychotic effects is still to be clarified, the majority of studies have focused on its ability to directly inhibit the reuptake of AEA. In agreement, in the RCT carried out by Leweke et al. [72], CBD increased AEA serum levels, and this increase was associated with a reduction in psychotic symptoms. However, other molecular targets were proposed. The partial agonist activity on dopamine D2 receptors might, at least in part, account for CBD's antipsychotic effects, and other authors suggested that it might act via 5-HT1A or TRPV1 receptors [66]. It is important to note that CBD is characterized by a more favorable safety profile, with only a few minor side effects, such as tiredness, diarrhea, and changes in appetite/weight [66].

\subsubsection{Animal Studies}

Consistent with clinical observations, preclinical data also showed an involvement of the endocannabinoid system in the pathophysiology of SCZ. For example, the pharmacological blockade of AEA degradation improved negative symptoms in both amphetamine- and phencyclidine-treated rats $[73,74]$. CB1R alterations in various animal models of schizophrenia-like disorders were also found [28]. Using the model of social isolation rearing, a decrease in CB1R expression was found in the caudate putamen and amygdala of phencyclidine-treated rats, whereas an increase was observed in the ventral tegmental area and amygdala $[75,76]$. Moreover, the administration of a CB2R antagonist exacerbated the MK-801- or methamphetamine-induced disturbance of prepulse inhibition involved in acoustic startle and hyperactivity in mice [77]. Preclinical studies also support the hypothesis that CBD might have antipsychotic properties. For example, CBD attenuated the amphetamine-disruptive effects on prepulse inhibition, as well as the hyperlocomotion induced by psychotomimetic drugs $[78,79]$.

\subsection{Anxiety Disorders}

Anxiety disorders are chronic, disabling conditions, including several syndromes such as generalized anxiety disorder (GAD), panic disorder (PD), social anxiety disorder (SAD), obsessivecompulsive disorder (OCD), and post-traumatic stress disorder (PTSD) [80]. These disorders represent the most prevalent mental illnesses in the world, with high societal costs [81]. Antidepressants and benzodiazepines are the main pharmacological treatments; however, $40-60 \%$ of patients do not attain total relief from their impairing symptoms [82]. Thus, there is a strong need to develop alternative treatments. In this regard, there is increasing interest in the endocannabinoid system as an important component of the complex circuitry involved in the control of responses to anxiety [83]. It is well established that cannabis consumption affects anxiety-related behaviors in a dose-dependent manner, with low doses being anxiolytic and high doses inducing adverse events, including increased anxiety and panic $[84,85]$. Data from animal tests further support the evidence of the bidirectional effects observed in humans: low doses of cannabinoids produced anxiolytic-like effects, while high doses produced anxiogenic-like responses [85]. The mechanisms underlying the effects of endocannabinoids on anxiety-related responses occur through CB1R, which is highly expressed in key structures within the brain directly involved in the modulation of emotional behavior, such as the PFC, amygdala, and hippocampus [86]. The involvement of CB1R was clarified using CB1-knockout mice. Under basal conditions, untreated CB1-knockout mice exhibited an increase in basal levels of anxiety-like responses compared to wild-type animals [87-89]. Moreover, CB1 deletion consistently caused anxiety under aversive conditions [88,90]. Furthermore, the anxiolytic effects of benzodiazepines appear to be less efficacious in CB1-knockout mice [89]. In contrast, Marsicano et al. (2002) found no alterations in anxiety-related responses between mutant and wild-type animals [91]. Using conditional mutant mice, the importance of the location of CB1R on specific neuronal subtypes with regards to biphasic effects was also demonstrated. CB1R located in glutamatergic neurons accounted for the anxiolytic effects of 
low doses, while CB1R located in $\gamma$-aminobutyric acid (GABA)-ergic neurons seems to be involved in the anxiogenic consequences of higher doses [92,93]. Experimental studies in animals showed that exposure to stress, both acute and chronic, appears to impair endocannabinoid signaling, with reduced AEA content in several brain regions, such as the PFC, hippocampus, and amygdala [94]. FAAH genetic variation also impacts enzyme expression and activity, thereby increasing AEA levels and attenuating anxiety-like behaviors in both mice and humans [95]. In agreement, the pharmacological blockade of FAAH was shown to reduce anxiety in a variety of animal models, such as the elevated plus maze and light-dark box test, and these effects were enhanced under aversive stimuli [96-98]. Altogether, these data indicate that the endocannabinoid system is clearly implicated in the modulation of anxiety, and its dysregulation may result in anxiety disorders. Thus, pharmacological modulation which enhances its signal was suggested as a target for the treatment of these disorders, and proposed drugs include $\triangle 9$-THC and CBD, among others [99].

\subsubsection{Human Studies}

It is well documented that patients with anxiety disorders, as well as subjects with high levels of anxiety, use cannabis to cope with their symptoms. For example, subjects with SAD seem to use cannabis as a form of "self-medication" [100]. Among returning veterans, the most frequently endorsed conditions for cannabis use were anxiety/stress and PTSD [101]. Moreover, several studies reported a strong correlation between PTSD symptom severity and the level of cannabis use [102]. When the effects of smoked cannabis were evaluated in PTSD patients, improvements in the Quality of Life Scale, pain scores, and the Clinician-Administered PTSD Scale (CAPS) were reported [103]. In agreement, Roitman et al. [104], in an open-label study, showed that, in patients with unremitted PTSD, treatment with orally absorbable $\triangle 9$-THC had beneficial effects on global symptom severity, sleep quality, frequency of nightmares, and PTSD hyperarousal symptoms. Importantly, a CB1R positron-emission tomography imaging study showed increased CB1R expression in the brains of individuals with PTSD compared to the control group [105]. The same authors also demonstrated that this increase was accompanied by a significant reduction in peripheral AEA concentration. Under other conditions, significant correlation between cannabis use and the prevalence of anxiety disorders was well documented [106]. As mentioned above, the effects of cannabis on anxiety appear to be dose-dependent, with low doses producing an anxiolytic effect and higher doses producing anxiogenic behavior. Accordingly, in healthy subjects, $\triangle 9$-THC was demonstrated to decrease and increase anxiety levels at low and higher doses, respectively [84]. Moreover, neuroimaging studies showed that, at specific doses, $\triangle 9$-THC could both increase and decrease negative emotional processing in healthy volunteers $[107,108]$. Unlike $\Delta 9$-THC, CBD showed anxiolytic effects in humans without inducing anxiogenic effects at high doses at baseline [109]. When co-administered with $\triangle 9$-THC, CBD was able to attenuate the anxiogenic effect of high doses of $\triangle 9$-THC $[68,110]$. Moreover, CBD was able to reduce post-stress anxiety in healthy subjects submitted to simulated public speaking (SPS), and this effect was comparable with that of isapirone, a selective 5-HT1A-receptor partial agonist [111]. Using the same procedure, CBD was also able to reduce an increase in anxiety induced by SPS on subjects with SAD [112]. Neuroimaging studies showed that the anxiolytic effect of CBD was related to functional changes in brain areas involved in the control of emotional processes. In healthy volunteers, as well as in patients with SAD, CBD induced a significant decrease in anxiety, as determined by single-photon emission computed tomography (SPECT), acting predominantly in limbic and paralimbic cortical areas (amygdala and the hippocampus, as well as the hypothalamus, the left posterior cingulate gyrus, and the left parahippocampal gyrus), which are usually implicated in the pathophysiology of anxiety $[113,114]$. Finally, CBD enhanced the extinction of fear memories in healthy subjects, acting at the amygdala and the anterior and posterior cingulate cortex [107]. 


\subsubsection{Animal Studies}

In agreement with the results obtained in clinical studies, preclinical evidence also showed the anxiolytic effects of CBD in several animal models of anxiety [109]. For example, in the elevated plus maze, CBD showed anxiolytic-like effects similar to diazepam in both rats and mice $[115,116]$. In the Vogel test, CBD also induced an anticonflict effect in rats, reducing the suppression of punished responses [117]. The use of these animal models also allowed the determination of the brain areas and the receptors involved in these effects. Indeed, anxiolytic effects were also found when CBD was microinjected into specific brain regions relevant to anxiety, including the central nucleus of the amygdala, the bed nucleus of the stria terminalis, and the dorsal periaqueductal gray [109]. Moreover, activation of the 5-HT1A receptor seems to mediate these effects, as they were attenuated by local treatment with the 5-HT1A-receptor antagonist, WAY100635 [118].

\subsection{Depression}

Depression is one of the most debilitating psychiatric disorders, affecting $20 \%$ of the population, characterized by sadness, emptiness, loss of interest or pleasure in everyday activities (anhedonia), impaired concentration or decision-making, psychomotor agitation or retardation, and insomnia or hypersomnia [119]. Antidepressants represent the first-line treatment prescribed for depression; however, not all patients achieve full remission, and many are unresponsive [120]. Consequently, depression tends to be chronic with high rates of recurrence and relapse [121]. In recent years, both clinical and preclinical evidence led to the hypothesis of a link between defects in the endocannabinoid system and depression [122].

\subsubsection{Human Studies}

A reduction in serum content of the endocannabinoid 2-AG was found in females diagnosed with major depression, while serum AEA content was not significantly altered [123,124]. Moreover, the magnitude of 2-AG reduction strictly correlated with the duration of the depressive episode. On the other hand, the same authors also showed that exposure to an acute social stressor evoked a significant increase in serum 2-AG content in both females diagnosed with major depression and healthy matched controls [124]. In human postmortem studies, CB1R density and functionality, as well as CB1 messenger RNA (mRNA) levels, were found elevated in the dorsolateral prefrontal cortex of depressed suicides [125,126]. On the contrary, Eggan et al. [44] did not find alterations in CB1R mRNA and protein levels in the dorsal prefrontal cortex in subjects with major depression. Furthermore, the expression of CB1R in the anterior cingulate cortex was found to be reduced in depressed patients treated with serotonin selective reuptake inhibitors [45]. Genetic studies demonstrated a link between polymorphisms in the CNR1 gene and increased vulnerability to developing a depressive episode following exposure to life stress [127], as well as increased risk of antidepressant resistance [128]. Both CNR1 and FAAH gene polymorphisms might also contribute to susceptibility to bipolar disorder and major depression [129]. Finally, genetic variability in the CNR1 gene seems to be involved in the etiology of major depression and in the clinical response to the selective serotonin reuptake inhibitor citalopram [130]. The evidence hereinbefore emphasizes that deficient endocannabinoid signaling may be implicated in the pathophysiology of depression; therefore, activation of the endocannabinoid system could represent a new pharmacological approach to treating patients. Anecdotal reports suggest that some individuals use cannabis to effectively treat depressive and manic symptoms [131-133]. For example, Gruber et al. [134] described five cases in which patients reported that cannabis relieved their depressive symptoms, and that they deliberately used it for this purpose. Moreover, a cross-sectional study showed that those who consume cannabis occasionally or even daily have lower levels of depressive symptoms than those who have never tried cannabis [134]. Babson et al. [135] reported that individuals with heightened depression symptoms had more severe problematic cannabis use because of the beneficial effects of cannabis on perceived sleep quality. Finally, in a recent systematic 
review, the authors identified seven cross-sectional studies in which there was clear evidence of an amelioration of depressed mood through the use of cannabis for medical purposes [136]. In bipolar disorder, it was found that some patients used cannabis to treat mania, depression, or both [131]. They also stated that it was more effective than conventional drugs, or helped relieve the side effects of those drugs. In agreement, an observational study showed that smoking cannabis acts to alleviate mood-related symptoms in at least a subset of bipolar patients [137]. Furthermore, two studies showed that cannabis use might be related to improved neurocognition in bipolar disorder [138,139]. On the other hand, a recent meta-analysis, including several longitudinal studies reporting on the association between cannabis and depression, concluded that cannabis use, particularly heavy use, may be associated with an increased risk of developing a depressive disorder [140]. Moreover, women with depressive disorders who used cannabis regularly reported poorer mental-health-related quality of life [141]. Cannabis use might also worsen the occurrence of manic symptoms in those diagnosed with bipolar disorder, and might also be associated with an increased risk of onset of new manic symptoms [142].

\subsubsection{Animal Studies}

Modifications of CB1R and other elements belonging to the endocannabinoid system were also reported in animal models of depression [143]. For example, exposure to chronic mild stress reduced 2-AG brain tissue concentration in the hippocampus [144], but increased it in the hypothalamus, midbrain [145], and thalamus [146], whereas AEA content decreased throughout the brain [145] or showed no changes [146]. Moreover, exposure to chronic mild stress increased CB1R density in the prefrontal cortex and decreased CB1R density in the hippocampus, hypothalamus, and ventral striatum [145]. Treatment with the antidepressants tranylcypromine and fluoxetine increased CB1R-binding density in the PFC and hippocampus, and tranylcypromine also reduced the tissue content of AEA in the PFC, hippocampus, and hypothalamus, while increasing 2-AG content in the PFC [147]. Nevertheless, the potential antidepressant action of its major constituents, $\triangle 9$-THC and CBD, was demonstrated in several animal models of behavioral despair, such as the forced-swimming test or the tail-suspension test $[148,149]$. Antidepressant effects were also evident when CBD was injected in a specific brain area with a key role in emotion, such as the PFC [150]. Genetic deletion of CB1R in mice led to the development of a phenotype characterized by depressive-like and anxiety-like behaviors, as well as by an anhedonic state and cognitive deficits [143].

\section{Conclusions}

Despite the growing knowledge base of neuropsychiatric disorder neurobiology, a high percentage of patients do not respond to first-line therapeutic interventions. Therefore, there is clearly a need for new, more effective treatments. The endocannabinoid system plays a key role in emotional responses and cognition function, and both clinical and preclinical studies suggest that dysregulation of its neuronal signaling may be involved in the pathophysiology of these disorders [27,28]. Thus, therapeutic strategies based on drugs that modulate endocannabinoid signaling may be useful in the treatment of neuropsychiatric disorders. Cannabis has been used for millennia for therapeutic purposes, and there are several anecdotal reports of its use as a form of self-medication for the alleviation of neuropsychiatric symptoms (e.g., anxiety, depression, and mania) [85,132]. On the other hand, epidemiological studies have consistently demonstrated that heavy cannabis use could be associated with the occurrence of psychiatric outcomes, especially in people at risk for psychosis or with mood disorders $[59,140]$. Thus, evidence supporting the use of cannabis for the treatment of neuropsychiatric disorders is equivocal, which is mainly due to the use of the whole plant. As we know, cannabis contains various phytocannabinoids, among which $\triangle 9-\mathrm{THC}$ and CBD are the major constituents. As already mentioned, $\triangle 9-\mathrm{THC}$ is the main psychoactive component of cannabis, and it is the active ingredient responsible for both psychotic or affective mental health outcomes [59,107]. In contrast, CBD represents the non-psychoactive component of the plant and has been found to 
have antipsychotic properties and to be anxiolytic $[67,111,149]$. The ratio of these two compounds in smoked cannabis varies, and accordingly, the effects on mental health also vary. For example, the use of cannabis containing high $\triangle 9$-THC and low CBD concentrations was associated with a higher risk of a first psychotic episode [151]. On the contrary, using cannabis with a high CBD content was associated with significantly lower degrees of psychotic symptoms [152]. In agreement, in healthy volunteers who smoked cannabis, it was demonstrated that individuals with hair traces of $\Delta 9$-THC only had higher levels of positive schizophrenia-like symptoms than those with hair traces of both $\triangle 9$-THC and CBD [153]. When RCTs investigated the effects of $\triangle 9$-THC and CBD separately in the management of psychiatric patients, preliminary results suggested that CBD may have potential efficacy in the treatment of psychotic and anxiety disorders $[70,109]$. Indeed, pretreatment of CBD significantly improves psychotic symptoms in schizophrenic patients and decreases anxiety in patients diagnosed with generalized SAD [71,72,112]. Also, CBD was well tolerated with only a few minor side effects [66]. Although the studies reviewed here provide clear evidence of the beneficial effects of CBD in the treatment of psychiatric disorders, RCTs with a small sample size and short duration limit its potential clinical utility. Moreover, in some cases, CBD was evaluated as an adjunct to traditional treatments [71]. Thus, further and larger RCTs will be necessary to confirm the efficacy and safety of CBD, as well as basic research to understand its potential mechanism of action.

Author Contributions: M.S. and P.F. conceived the study; P.M. and M.D. formally analyzed and investigated the literature; P.M. and M.D. first drafted the manuscript; M.S., G.T., W.F. and P.F. reviewed and edited the manuscript.

Funding: This work was supported in part by funds from the Department of Biomedical Sciences Project (RICDIP_2012_Fratta_01), University of Cagliari, and in part by Medication Development Program funds, National Institute on Drug Abuse - Intramural Research Program, National Institutes of Health, Department of Health and Human Services, to G.T. (ZIA DA000569).

Conflicts of Interest: The authors declare no conflict of interest.

\section{References}

1. Iversen, L.L. The Science of Marijuana, 2nd ed.; Oxford University Press: Oxford, UK, 2007; ISBN 978-0-19-532824-0.

2. Zuardi, A.W. History of cannabis as a medicine: A review. Rev. Bras. Psiquiatr. 2006, 28, 153-157. [CrossRef] [PubMed]

3. O'Shaughnessy, W.B. New Remedy for Tetanus and Other Convulsive Disorders. Boston Med. Surg. J. 1840, 23, 153-155. [CrossRef]

4. Moreau, J.-J. Du Hachisch et de L'Aliénationmentale, Étudespsychologiques, Par J. Moreau de Tours; Fortin, Masson et Cie: Paris, France, 1845.

5. Grinspoon. Marihuana Reconsidered, 2nd ed.; Quick American Archives: Oakland, CA, USA, 1994; ISBN 978-0-932551-13-9.

6. Brenneisen, R. Chemistry and Analysis of Phytocannabinoids and Other Cannabis Constituents. In Marijuana and the Cannabinoids; ElSohly, M.A., Ed.; Humana Press: Totowa, NJ, USA, 2007; pp. 17-49, ISBN 978-1-58829-456-2.

7. Adams, R.; Hunt, M.; Clark, J.H. Structure of cannabidiol, a product isolated from the marihuana extract of Minnesota wild hemp. I. J. Am. Chem. Soc. 1940, 62, 196-200. [CrossRef]

8. Mechoulam, R.; Shvo, Y. Hashish-I: The structure of cannabidiol. Tetrahedron 1963, 19, 2073-2078. [CrossRef]

9. Gaoni, Y.; Mechoulam, R. Isolation, structure, and partial synthesis of an active constituent of hashish. J. Am. Chem. Soc. 1964, 86, 1646-1647. [CrossRef]

10. Mechoulam, R.; Braun, P.; Gaoni, Y. A stereospecific synthesis of (-)-delta 1- and (-)-delta 1(6)tetrahydrocannabinols. J. Am. Chem. Soc. 1967, 89, 4552-4554. [CrossRef] [PubMed]

11. Leuschner, J.T.; Wing, D.R.; Harvey, D.J.; Brent, G.A.; Dempsey, C.E.; Watts, A.; Paton, W.D. The partitioning of delta 1-tetrahydrocannabinol into erythrocyte membranes in vivo and its effect on membrane fluidity. Experientia 1984, 40, 866-868. [CrossRef] [PubMed]

12. Howlett, A.C.; Scott, D.K.; Wilken, G.H. Regulation of adenylate cyclase by cannabinoid drugs. Insights based on thermodynamic studies. Biochem. Pharmacol. 1989, 38, 3297-3304. [CrossRef] 
13. Matsuda, L.A.; Lolait, S.J.; Brownstein, M.J.; Young, A.C.; Bonner, T.I. Structure of a cannabinoid receptor and functional expression of the cloned cDNA. Nature 1990, 346, 561-564. [CrossRef] [PubMed]

14. Mackie, K. Distribution of cannabinoid receptors in the central and peripheral nervous system. Handb. Exp. Pharmacol. 2005, 168, 299-325.

15. Munro, S.; Thomas, K.L.; Abu-Shaar, M. Molecular characterization of a peripheral receptor for cannabinoids. Nature 1993, 365, 61-65. [CrossRef] [PubMed]

16. Howlett, A.C. The cannabinoid receptors. Prostaglandins Other Lipid Mediat. 2002, 68-69, 619-631. [CrossRef]

17. Ryberg, E.; Larsson, N.; Sjögren, S.; Hjorth, S.; Hermansson, N.-O.; Leonova, J.; Elebring, T.; Nilsson, K.; Drmota, T.; Greasley, P.J. The orphan receptor GPR55 is a novel cannabinoid receptor. Br. J. Pharmacol. 2007, 152, 1092-1101. [CrossRef] [PubMed]

18. Pertwee, R.G. Receptors and channels targeted by synthetic cannabinoid receptor agonists and antagonists. Curr. Med. Chem. 2010, 17, 1360-1381. [CrossRef] [PubMed]

19. Devane, W.A.; Hanus, L.; Breuer, A.; Pertwee, R.G.; Stevenson, L.A.; Griffin, G.; Gibson, D.; Mandelbaum, A.; Etinger, A.; Mechoulam, R. Isolation and structure of a brain constituent that binds to the cannabinoid receptor. Science 1992, 258, 1946-1949. [CrossRef] [PubMed]

20. Sugiura, T.; Kondo, S.; Sukagawa, A.; Nakane, S.; Shinoda, A.; Itoh, K.; Yamashita, A.; Waku, K. 2-Arachidonoylglycerol: A possible endogenous cannabinoid receptor ligand in brain. Biochem. Biophys. Res. Commun. 1995, 215, 89-97. [CrossRef] [PubMed]

21. Marzo, V.D.; Petrocellis, L.D. Why do cannabinoid receptors have more than one endogenous ligand? Phil. Trans. R. Soc. B 2012, 367, 3216-3228. [CrossRef] [PubMed]

22. Mechoulam, R.; Hanuš, L.O.; Pertwee, R.; Howlett, A.C. Early phytocannabinoid chemistry to endocannabinoids and beyond. Nat. Rev. Neurosci. 2014, 15, 757-764. [CrossRef] [PubMed]

23. Piomelli, D. The molecular logic of endocannabinoid signalling. Nat. Rev. Neurosci. 2003, 4, 873-884. [CrossRef] [PubMed]

24. Cravatt, B.F.; Demarest, K.; Patricelli, M.P.; Bracey, M.H.; Giang, D.K.; Martin, B.R.; Lichtman, A.H. Supersensitivity to anandamide and enhanced endogenous cannabinoid signaling in mice lacking fatty acid amide hydrolase. Proc. Natl. Acad. Sci. USA 2001, 98, 9371-9376. [CrossRef] [PubMed]

25. Fegley, D.; Gaetani, S.; Duranti, A.; Tontini, A.; Mor, M.; Tarzia, G.; Piomelli, D. Characterization of the fatty acid amide hydrolase inhibitor cyclohexyl carbamic acid 3'-carbamoyl-biphenyl-3-yl ester (URB597): Effects on anandamide and oleoylethanolamide deactivation. J. Pharmacol. Exp. Ther. 2005, 313, 352-358. [CrossRef] [PubMed]

26. Katona, I.; Freund, T.F. Multiple functions of endocannabinoid signaling in the brain. Annu. Rev. Neurosci. 2012, 35, 529-558. [CrossRef] [PubMed]

27. Fernández-Ruiz, J.; Hernández, M.; Ramos, J.A. Cannabinoid-dopamine interaction in the pathophysiology and treatment of CNS disorders. CNS Neurosci. Ther. 2010, 16, e72-e91. [CrossRef] [PubMed]

28. Rubino, T.; Zamberletti, E.; Parolaro, D. Endocannabinoids and mental disorders. Handb. Exp. Pharmacol. 2015, 231, 261-283. [CrossRef] [PubMed]

29. Diagnostic and Statistical Manual of Mental Disorders (DSM-5). Available online: https:/ /www.psychiatry. org/psychiatrists/practice/dsm (accessed on 30 July 2018).

30. Harvey, P.D.; Koren, D.; Reichenberg, A.; Bowie, C.R. Negative symptoms and cognitive deficits: What is the nature of their relationship? Schizophr. Bull. 2006, 32, 250-258. [CrossRef] [PubMed]

31. McGrath, J.; Saha, S.; Chant, D.; Welham, J. Schizophrenia: A concise overview of incidence, prevalence, and mortality. Epidemiol. Rev. 2008, 30, 67-76. [CrossRef] [PubMed]

32. Leweke, F.M.; Odorfer, T.M.; Bumb, J.M. Medical needs in the treatment of psychotic disorders. Handb. Exp. Pharmacol. 2012, 212, 165-185. [CrossRef]

33. Patel, K.R.; Cherian, J.; Gohil, K.; Atkinson, D. Schizophrenia: Overview and treatment options. Pharm. Ther. 2014, 39, 638-645.

34. Müller-Vahl, K.R.; Emrich, H.M. Cannabis and schizophrenia: Towards a cannabinoid hypothesis of schizophrenia. Expert Rev. Neurother. 2008, 8, 1037-1048. [CrossRef] [PubMed]

35. Ferretjans, R.; Moreira, F.A.; Teixeira, A.L.; Salgado, J.V. The endocannabinoid system and its role in schizophrenia: A systematic review of the literature. Rev. Bras. Psiquiatr. 2012, 34 (Suppl. 2), S163-S177. [CrossRef] [PubMed] 
36. Leweke, F.M.; Giuffrida, A.; Wurster, U.; Emrich, H.M.; Piomelli, D. Elevated endogenous cannabinoids in schizophrenia. Neuroreport 1999, 10, 1665-1669. [CrossRef] [PubMed]

37. De Marchi, N.; De Petrocellis, L.; Orlando, P.; Daniele, F.; Fezza, F.; Di Marzo, V. Endocannabinoid signalling in the blood of patients with schizophrenia. Lipids Health Dis. 2003, 2, 5. [CrossRef] [PubMed]

38. Giuffrida, A.; Leweke, F.M.; Gerth, C.W.; Schreiber, D.; Koethe, D.; Faulhaber, J.; Klosterkötter, J.; Piomelli, D. Cerebrospinal anandamide levels are elevated in acute schizophrenia and are inversely correlated with psychotic symptoms. Neuropsychopharmacology 2004, 29, 2108-2114. [CrossRef] [PubMed]

39. Leweke, F.M.; Giuffrida, A.; Koethe, D.; Schreiber, D.; Nolden, B.M.; Kranaster, L.; Neatby, M.A.; Schneider, M.; Gerth, C.W.; Hellmich, M.; et al. Anandamide levels in cerebrospinal fluid of first-episode schizophrenic patients: Impact of cannabis use. Schizophr. Res. 2007, 94, 29-36. [CrossRef] [PubMed]

40. Dean, B.; Sundram, S.; Bradbury, R.; Scarr, E.; Copolov, D. Studies on [3H]CP-55940 binding in the human central nervous system: Regional specific changes in density of cannabinoid-1 receptors associated with schizophrenia and cannabis use. Neuroscience 2001, 103, 9-15. [CrossRef]

41. Newell, K.A.; Deng, C.; Huang, X.-F. Increased cannabinoid receptor density in the posterior cingulate cortex in schizophrenia. Exp. Brain Res. 2006, 172, 556-560. [CrossRef] [PubMed]

42. Zavitsanou, K.; Garrick, T.; Huang, X.F. Selective antagonist [3H]SR141716A binding to cannabinoid CB1 receptors is increased in the anterior cingulate cortex in schizophrenia. Prog. Neuropsychopharmacol. Biol. Psychiatry 2004, 28, 355-360. [CrossRef] [PubMed]

43. Eggan, S.M.; Hashimoto, T.; Lewis, D.A. Reduced cortical cannabinoid 1 receptor messenger RNA and protein expression in schizophrenia. Arch. Gen. Psychiatry 2008, 65, 772-784. [CrossRef] [PubMed]

44. Eggan, S.M.; Stoyak, S.R.; Verrico, C.D.; Lewis, D.A. Cannabinoid CB1 receptor immunoreactivity in the prefrontal cortex: Comparison of schizophrenia and major depressive disorder. Neuropsychopharmacology 2010, 35, 2060-2071. [CrossRef] [PubMed]

45. Koethe, D.; Llenos, I.C.; Dulay, J.R.; Hoyer, C.; Torrey, E.F.; Leweke, F.M.; Weis, S. Expression of CB1 cannabinoid receptor in the anterior cingulate cortex in schizophrenia, bipolar disorder, and major depression. J. Neural Transm. 2007, 114, 1055-1063. [CrossRef] [PubMed]

46. Urigüen, L.; García-Fuster, M.J.; Callado, L.F.; Morentin, B.; La Harpe, R.; Casadó, V.; Lluis, C.; Franco, R.; García-Sevilla, J.A.; Meana, J.J. Immunodensity and mRNA expression of A2A adenosine, D2 dopamine, and CB1 cannabinoid receptors in postmortem frontal cortex of subjects with schizophrenia: Effect of antipsychotic treatment. Psychopharmacology 2009, 206, 313-324. [CrossRef] [PubMed]

47. Ceccarini, J.; De Hert, M.; Van Winkel, R.; Peuskens, J.; Bormans, G.; Kranaster, L.; Enning, F.; Koethe, D.; Leweke, F.M.; Van Laere, K. Increased ventral striatal CB1 receptor binding is related to negative symptoms in drug-free patients with schizophrenia. NeuroImage 2013, 79, 304-312. [CrossRef] [PubMed]

48. Wong, D.F.; Kuwabara, H.; Horti, A.G.; Raymont, V.; Brasic, J.; Guevara, M.; Ye, W.; Dannals, R.F.; Ravert, H.T.; Nandi, A.; et al. Quantification of cerebral cannabinoid receptors subtype 1 (CB1) in healthy subjects and schizophrenia by the novel PET radioligand $\left[{ }^{11} \mathrm{C}\right.$ ]OMAR. NeuroImage 2010, 52, 1505-1513. [CrossRef] [PubMed]

49. Horti, A.G.; Fan, H.; Kuwabara, H.; Hilton, J.; Ravert, H.T.; Holt, D.P.; Alexander, M.; Kumar, A.; Rahmim, A.; Scheffel, U.; et al. ${ }^{11}$ C-JHU75528: A radiotracer for PET imaging of CB1 cannabinoid receptors. J. Nucl. Med. Off. Publ. Soc. Nucl. Med. 2006, 47, 1689-1696.

50. Bioque, M.; García-Bueno, B.; MacDowell, K.S.; Meseguer, A.; Saiz, P.A.; Parellada, M.; Gonzalez-Pinto, A.; Rodriguez-Jimenez, R.; Lobo, A.; Leza, J.C.; et al. Peripheral endocannabinoid system dysregulation in first-episode psychosis. Neuropsychopharmacology 2013, 38, 2568-2577. [CrossRef] [PubMed]

51. Ujike, H.; Morita, Y. New perspectives in the studies on endocannabinoid and cannabis: Cannabinoid receptors and schizophrenia. J. Pharmacol. Sci. 2004, 96, 376-381. [CrossRef] [PubMed]

52. Chavarría-Siles, I.; Contreras-Rojas, J.; Hare, E.; Walss-Bass, C.; Quezada, P.; Dassori, A.; Contreras, S.; Medina, R.; Ramírez, M.; Salazar, R.; et al. Cannabinoid receptor 1 gene (CNR1) and susceptibility to a quantitative phenotype for hebephrenic schizophrenia. Am. J. Med. Genet. Part B 2008, 147B, 279-284. [CrossRef] [PubMed]

53. Tsai, S.J.; Wang, Y.C.; Hong, C.J. Association study of a cannabinoid receptor gene (CNR1) polymorphism and schizophrenia. Psychiatr. Genet. 2000, 10, 149-151. [CrossRef] [PubMed]

54. Seifert, J.; Ossege, S.; Emrich, H.M.; Schneider, U.; Stuhrmann, M. No association of CNR1 gene variations with susceptibility to schizophrenia. Neurosci. Lett. 2007, 426, 29-33. [CrossRef] [PubMed] 
55. Moore, T.H.M.; Zammit, S.; Lingford-Hughes, A.; Barnes, T.R.E.; Jones, P.B.; Burke, M.; Lewis, G. Cannabis use and risk of psychotic or affective mental health outcomes: A systematic review. Lancet Lond. Engl. 2007, 370, 319-328. [CrossRef]

56. Jiang, S.; Fu, Y.; Williams, J.; Wood, J.; Pandarinathan, L.; Avraham, S.; Makriyannis, A.; Avraham, S.; Avraham, H.K. Expression and function of cannabinoid receptors CB1 and CB2 and their cognate cannabinoid ligands in murine embryonic stem cells. PLoS ONE 2007, 2, e641. [CrossRef] [PubMed]

57. Potvin, S.; Joyal, C.C.; Pelletier, J.; Stip, E. Contradictory cognitive capacities among substance-abusing patients with schizophrenia: A meta-analysis. Schizophr. Res. 2008, 100, 242-251. [CrossRef] [PubMed]

58. D'Souza, D.C.; Perry, E.; MacDougall, L.; Ammerman, Y.; Cooper, T.; Wu, Y.-T.; Braley, G.; Gueorguieva, R.; Krystal, J.H. The psychotomimetic effects of intravenous delta-9-tetrahydrocannabinol in healthy individuals: Implications for psychosis. Neuropsychopharmacology 2004, 29, 1558-1572. [CrossRef] [PubMed]

59. D'Souza, D.C.; Abi-Saab, W.M.; Madonick, S.; Forselius-Bielen, K.; Doersch, A.; Braley, G.; Gueorguieva, R.; Cooper, T.B.; Krystal, J.H. Delta-9-tetrahydrocannabinol effects in schizophrenia: Implications for cognition, psychosis, and addiction. Biol. Psychiatry 2005, 57, 594-608. [CrossRef] [PubMed]

60. Bossong, M.G.; Jager, G.; Bhattacharyya, S.; Allen, P. Acute and non-acute effects of cannabis on human memory function: A critical review of neuroimaging studies. Curr. Pharm. Des. 2014, 20, 2114-2125. [CrossRef] [PubMed]

61. Murray, R.M.; Englund, A.; Abi-Dargham, A.; Lewis, D.A.; Di Forti, M.; Davies, C.; Sherif, M.; McGuire, P.; D'Souza, D.C. Cannabis-associated psychosis: Neural substrate and clinical impact. Neuropharmacology 2017, 124, 89-104. [CrossRef] [PubMed]

62. Schwarcz, G.; Karajgi, B.; McCarthy, R. Synthetic delta-9-tetrahydrocannabinol (dronabinol) can improve the symptoms of schizophrenia. J. Clin. Psychopharmacol. 2009, 29, 255-258. [CrossRef] [PubMed]

63. Pertwee, R.G.; Ross, R.A.; Craib, S.J.; Thomas, A. (-)-Cannabidiol antagonizes cannabinoid receptor agonists and noradrenaline in the mouse vas deferens. Eur. J. Pharmacol. 2002, 456, 99-106. [CrossRef]

64. Bisogno, T.; Hanus, L.; De Petrocellis, L.; Tchilibon, S.; Ponde, D.E.; Brandi, I.; Moriello, A.S.; Davis, J.B.; Mechoulam, R.; Di Marzo, V. Molecular targets for cannabidiol and its synthetic analogues: Effect on vanilloid VR1 receptors and on the cellular uptake and enzymatic hydrolysis of anandamide. Br. J. Pharmacol. 2001, 134, 845-852. [CrossRef] [PubMed]

65. Seeman, P. Cannabidiol is a partial agonist at dopamine D2High receptors, predicting its antipsychotic clinical dose. Transl. Psychiatry 2016, 6, e920. [CrossRef] [PubMed]

66. Hahn, B. The potential of cannabidiol treatment for cannabis users with recent-onset psychosis. Schizophr. Bull. 2018, 44, 46-53. [CrossRef] [PubMed]

67. Mandolini, G.M.; Lazzaretti, M.; Pigoni, A.; Oldani, L.; Delvecchio, G.; Brambilla, P. Pharmacological properties of cannabidiol in the treatment of psychiatric disorders: A critical overview. Epidemiol. Psychiatr. Sci. 2018, 27, 327-335. [CrossRef] [PubMed]

68. Bhattacharyya, S.; Morrison, P.D.; Fusar-Poli, P.; Martin-Santos, R.; Borgwardt, S.; Winton-Brown, T.; Nosarti, C.; O' Carroll, C.M.; Seal, M.; Allen, P.; et al. Opposite effects of delta-9-tetrahydrocannabinol and cannabidiol on human brain function and psychopathology. Neuropsychopharmacology 2010, 35, 764-774. [CrossRef] [PubMed]

69. Zuardi, A.W.; Morais, S.L.; Guimarães, F.S.; Mechoulam, R. Antipsychotic effect of cannabidiol. J. Clin. Psychiatry 1995, 56, 485-486. [PubMed]

70. Zuardi, A.W.; Crippa, J.A.S.; Hallak, J.E.C.; Moreira, F.A.; Guimarães, F.S. Cannabidiol, a Cannabis sativa constituent, as an antipsychotic drug. Braz. J. Med. Biol. Res. Rev. 2006, 39, 421-429. [CrossRef]

71. McGuire, P.; Robson, P.; Cubala, W.J.; Vasile, D.; Morrison, P.D.; Barron, R.; Taylor, A.; Wright, S. Cannabidiol (CBD) as an adjunctive therapy in schizophrenia: A multicenter randomized controlled trial. Am. J. Psychiatry 2018, 175, 225-231. [CrossRef] [PubMed]

72. Leweke, F.M.; Piomelli, D.; Pahlisch, F.; Muhl, D.; Gerth, C.W.; Hoyer, C.; Klosterkötter, J.; Hellmich, M.; Koethe, D. Cannabidiol enhances anandamide signaling and alleviates psychotic symptoms of schizophrenia. Transl. Psychiatry 2012, 2, e94. [CrossRef] [PubMed]

73. Beltramo, M.; de Fonseca, F.R.; Navarro, M.; Calignano, A.; Gorriti, M.A.; Grammatikopoulos, G.; Sadile, A.G.; Giuffrida, A.; Piomelli, D. Reversal of dopamine D2 receptor responses by an anandamide transport inhibitor. J. Neurosci. Off. J. Soc. Neurosci. 2000, 20, 3401-3407. [CrossRef] 
74. Seillier, A.; Advani, T.; Cassano, T.; Hensler, J.G.; Giuffrida, A. Inhibition of fatty-acid amide hydrolase and CB1 receptor antagonism differentially affect behavioural responses in normal and PCP-treated rats. Int. J. Neuropsychopharmacol. 2010, 13, 373-386. [CrossRef] [PubMed]

75. Malone, D.T.; Kearn, C.S.; Chongue, L.; Mackie, K.; Taylor, D.A. Effect of social isolation on CB1 and D2 receptor and fatty acid amide hydrolase expression in rats. Neuroscience 2008, 152, 265-272. [CrossRef] [PubMed]

76. Vigano, D.; Guidali, C.; Petrosino, S.; Realini, N.; Rubino, T.; Di Marzo, V.; Parolaro, D. Involvement of the endocannabinoid system in phencyclidine-induced cognitive deficits modelling schizophrenia. Int. J. Neuropsychopharmacol. 2009, 12, 599-614. [CrossRef] [PubMed]

77. Ishiguro, H.; Horiuchi, Y.; Ishikawa, M.; Koga, M.; Imai, K.; Suzuki, Y.; Morikawa, M.; Inada, T.; Watanabe, Y.; Takahashi, M.; et al. Brain cannabinoid CB2 receptor in schizophrenia. Biol. Psychiatry 2010, 67, 974-982. [CrossRef] [PubMed]

78. Pedrazzi, J.F.C.; Issy, A.C.; Gomes, F.V.; Guimarães, F.S.; Del-Bel, E.A. Cannabidiol effects in the prepulse inhibition disruption induced by amphetamine. Psychopharmacology 2015, 232, 3057-3065. [CrossRef] [PubMed]

79. Moreira, F.A.; Guimarães, F.S. Cannabidiol inhibits the hyperlocomotion induced by psychotomimetic drugs in mice. Eur. J. Pharmacol. 2005, 512, 199-205. [CrossRef] [PubMed]

80. Craske, M.G.; Stein, M.B. Anxiety. Lancet 2016, 388, 3048-3059. [CrossRef]

81. Kessler, R.C.; Ruscio, A.M.; Shear, K.; Wittchen, H.-U. Epidemiology of anxiety disorders. Curr. Top. Behav. Neurosci. 2010, 2, 21-35. [PubMed]

82. Bandelow, B.; Zohar, J.; Hollander, E.; Kasper, S.; Möller, H.-J.; WFSBP Task Force on Treatment Guidelines for Anxiety Obsessive-Compulsive Post-Traumatic Stress Disoders. World Federation of Societies of Biological Psychiatry (WFSBP) guidelines for the pharmacological treatment of anxiety, obsessive-compulsive and post-traumatic stress disorders-First revision. World J. Biol. Psychiatry 2008, 9, 248-312. [CrossRef] [PubMed]

83. Rubino, T.; Guidali, C.; Vigano, D.; Realini, N.; Valenti, M.; Massi, P.; Parolaro, D. CB1 receptor stimulation in specific brain areas differently modulate anxiety-related behaviour. Neuropharmacology 2008, 54, 151-160. [CrossRef] [PubMed]

84. Viveros, M.P.; Marco, E.M.; File, S.E. Endocannabinoid system and stress and anxiety responses. Pharmacol. Biochem. Behav. 2005, 81, 331-342. [CrossRef] [PubMed]

85. Turna, J.; Patterson, B.; Van Ameringen, M. Is cannabis treatment for anxiety, mood, and related disorders ready for prime time? Depress. Anxiety 2017, 34, 1006-1017. [CrossRef] [PubMed]

86. Herkenham, M.; Lynn, A.B.; Little, M.D.; Johnson, M.R.; Melvin, L.S.; de Costa, B.R.; Rice, K.C. Cannabinoid receptor localization in brain. Proc. Natl. Acad. Sci. USA 1990, 87, 1932-1936. [CrossRef] [PubMed]

87. Martin, M.; Ledent, C.; Parmentier, M.; Maldonado, R.; Valverde, O. Involvement of CB1 cannabinoid receptors in emotional behaviour. Psychopharmacology 2002, 159, 379-387. [CrossRef] [PubMed]

88. Haller, J.; Varga, B.; Ledent, C.; Freund, T.F. CB1 cannabinoid receptors mediate anxiolytic effects: Convergent genetic and pharmacological evidence with CB1-specific agents. Behav. Pharmacol. 2004, 15, $299-304$. [CrossRef] [PubMed]

89. Urigüen, L.; Pérez-Rial, S.; Ledent, C.; Palomo, T.; Manzanares, J. Impaired action of anxiolytic drugs in mice deficient in cannabinoid CB1 receptors. Neuropharmacology 2004, 46, 966-973. [CrossRef] [PubMed]

90. Mikics, E.; Vas, J.; Aliczki, M.; Halasz, J.; Haller, J. Interactions between the anxiogenic effects of CB1 gene disruption and 5-HT3 neurotransmission. Behav. Pharmacol. 2009, 20, 265-272. [CrossRef] [PubMed]

91. Marsicano, G.; Wotjak, C.T.; Azad, S.C.; Bisogno, T.; Rammes, G.; Cascio, M.G.; Hermann, H.; Tang, J.; Hofmann, C.; Zieglgänsberger, W.; et al. The endogenous cannabinoid system controls extinction of aversive memories. Nature 2002, 418, 530-534. [CrossRef] [PubMed]

92. Rey, A.A.; Purrio, M.; Viveros, M.-P.; Lutz, B. Biphasic effects of cannabinoids in anxiety responses: $\mathrm{CB} 1$ and $\mathrm{GABA}_{\mathrm{B}}$ receptors in the balance of GABAergic and glutamatergic neurotransmission. Neuropsychopharmacology 2012, 37, 2624-2634. [CrossRef] [PubMed]

93. Jacob, W.; Yassouridis, A.; Marsicano, G.; Monory, K.; Lutz, B.; Wotjak, C.T. Endocannabinoids render exploratory behaviour largely independent of the test aversiveness: Role of glutamatergic transmission. Genes Brain Behav. 2009, 8, 685-698. [CrossRef] [PubMed]

94. Morena, M.; Patel, S.; Bains, J.S.; Hill, M.N. Neurobiological interactions between stress and the endocannabinoid system. Neuropsychopharmacology 2016, 41, 80-102. [CrossRef] [PubMed] 
95. Dincheva, I.; Drysdale, A.T.; Hartley, C.A.; Johnson, D.C.; Jing, D.; King, E.C.; Ra, S.; Gray, J.M.; Yang, R.; DeGruccio, A.M.; et al. FAAH genetic variation enhances fronto-amygdala function in mouse and human. Nat. Commun. 2015, 6, 6395. [CrossRef] [PubMed]

96. Kathuria, S.; Gaetani, S.; Fegley, D.; Valiño, F.; Duranti, A.; Tontini, A.; Mor, M.; Tarzia, G.; La Rana, G.; Calignano, A.; et al. Modulation of anxiety through blockade of anandamide hydrolysis. Nat. Med. 2003, 9, 76-81. [CrossRef] [PubMed]

97. Scherma, M.; Medalie, J.; Fratta, W.; Vadivel, S.K.; Makriyannis, A.; Piomelli, D.; Mikics, E.; Haller, J.; Yasar, S.; Tanda, G.; et al. The endogenous cannabinoid anandamide has effects on motivation and anxiety that are revealed by fatty acid amide hydrolase (FAAH) inhibition. Neuropharmacology 2008, 54, 129-140. [CrossRef] [PubMed]

98. Haller, J.; Barna, I.; Barsvari, B.; Gyimesi Pelczer, K.; Yasar, S.; Panlilio, L.V.; Goldberg, S. Interactions between environmental aversiveness and the anxiolytic effects of enhanced cannabinoid signaling by FAAH inhibition in rats. Psychopharmacology 2009, 204, 607-616. [CrossRef] [PubMed]

99. Hill, A.J.; Williams, C.M.; Whalley, B.J.; Stephens, G.J. Phytocannabinoids as novel therapeutic agents in CNS disorders. Pharmacol. Ther. 2012, 133, 79-97. [CrossRef] [PubMed]

100. Buckner, J.D.; Schmidt, N.B.; Lang, A.R.; Small, J.W.; Schlauch, R.C.; Lewinsohn, P.M. Specificity of social anxiety disorder as a risk factor for alcohol and cannabis dependence. J. Psychiatr. Res. 2008, 42, 230-239. [CrossRef] [PubMed]

101. Metrik, J.; Bassett, S.S.; Aston, E.R.; Jackson, K.M.; Borsari, B. Medicinal versus recreational cannabis use among returning veterans. Transl. Issues Psychol. Sci. 2018, 4, 6-20. [CrossRef] [PubMed]

102. Passie, T.; Emrich, H.M.; Karst, M.; Brandt, S.D.; Halpern, J.H. Mitigation of post-traumatic stress symptoms by Cannabis resin: A review of the clinical and neurobiological evidence. Drug Test. Anal. 2012, 4, 649-659. [CrossRef] [PubMed]

103. Reznik, I. Post-traumatic stress disorder and medical cannabis use: A naturalistic observational study. Eur. Neuropsychopharmacol. 2012, 22, S363-S364. [CrossRef]

104. Roitman, P.; Mechoulam, R.; Cooper-Kazaz, R.; Shalev, A. Preliminary, open-label, pilot study of add-on oral $\Delta$ 9-tetrahydrocannabinol in chronic post-traumatic stress disorder. Clin. Drug Investig. 2014, 34, 587-591. [CrossRef] [PubMed]

105. Neumeister, A.; Normandin, M.D.; Pietrzak, R.H.; Piomelli, D.; Zheng, M.Q.; Gujarro-Anton, A.; Potenza, M.N.; Bailey, C.R.; Lin, S.F.; Najafzadeh, S.; et al. Elevated brain cannabinoid CB1 receptor availability in post-traumatic stress disorder: A positron emission tomography study. Mol. Psychiatry 2013, 18, 1034-1040. [CrossRef] [PubMed]

106. Thomas, H. Psychiatric symptoms in cannabis users. Br. J. Psychiatry 1993, 163, 141-149. [CrossRef] [PubMed]

107. Fusar-Poli, P.; Crippa, J.A.; Bhattacharyya, S.; Borgwardt, S.J.; Allen, P.; Martin-Santos, R.; Seal, M.; Surguladze, S.A.; O'Carrol, C.; Atakan, Z.; et al. Distinct effects of $\Delta$ 9-tetrahydrocannabinol and cannabidiol on neural activation during emotional processing. Arch. Gen. Psychiatry 2009, 66, 95-105. [CrossRef] [PubMed]

108. Bossong, M.G.; van Hell, H.H.; Jager, G.; Kahn, R.S.; Ramsey, N.F.; Jansma, J.M. The endocannabinoid system and emotional processing: A pharmacological fMRI study with $\Delta$-tetrahydrocannabinol. Eur. Neuropsychopharmacol. J. Eur. Coll. Neuropsychopharmacol. 2013, 23, 1687-1697. [CrossRef] [PubMed]

109. Blessing, E.M.; Steenkamp, M.M.; Manzanares, J.; Marmar, C.R. Cannabidiol as a potential treatment for anxiety disorders. Neurother. J. Am. Soc. Exp. Neurother. 2015, 12, 825-836. [CrossRef] [PubMed]

110. Zuardi, A.W.; Shirakawa, I.; Finkelfarb, E.; Karniol, I.G. Action of cannabidiol on the anxiety and other effects produced by delta 9-THC in normal subjects. Psychopharmacology 1982, 76, 245-250. [CrossRef] [PubMed]

111. Zuardi, A.W.; Cosme, R.A.; Graeff, F.G.; Guimarães, F.S. Effects of ipsapirone and cannabidiol on human experimental anxiety. J. Psychopharmacol. 1993, 7, 82-88. [CrossRef] [PubMed]

112. Bergamaschi, M.M.; Queiroz, R.H.C.; Chagas, M.H.N.; de Oliveira, D.C.G.; De Martinis, B.S.; Kapczinski, F.; Quevedo, J.; Roesler, R.; Schröder, N.; Nardi, A.E.; et al. Cannabidiol reduces the anxiety induced by simulated public speaking in treatment-naïve social phobia patients. Neuropsychopharmacology 2011, 36, 1219-1226. [CrossRef] [PubMed]

113. Crippa, J.A.; Zuardi, A.W.; Garrido, G.E.J.; Wichert-Ana, L.; Guarnieri, R.; Ferrari, L.; Azevedo-Marques, P.M.; Hallak, J.E.C.; McGuire, P.K.; Filho Busatto, G. Effects of cannabidiol (CBD) on regional cerebral blood flow. Neuropsychopharmacology 2004, 29, 417-426. [CrossRef] [PubMed] 
114. Crippa, J.A.S.; Derenusson, G.N.; Ferrari, T.B.; Wichert-Ana, L.; Duran, F.L.S.; Martin-Santos, R.; Simões, M.V.; Bhattacharyya, S.; Fusar-Poli, P.; Atakan, Z.; et al. Neural basis of anxiolytic effects of cannabidiol (CBD) in generalized social anxiety disorder: A preliminary report. J. Psychopharmacol. 2011, 25, 121-130. [CrossRef] [PubMed]

115. Guimarães, F.S.; Chiaretti, T.M.; Graeff, F.G.; Zuardi, A.W. Antianxiety effect of cannabidiol in the elevated plus-maze. Psychopharmacology 1990, 100, 558-559. [CrossRef] [PubMed]

116. Onaivi, E.S.; Green, M.R.; Martin, B.R. Pharmacological characterization of cannabinoids in the elevated plus maze. J. Pharmacol. Exp. Ther. 1990, 253, 1002-1009. [PubMed]

117. Moreira, F.A.; Aguiar, D.C.; Guimarães, F.S. Anxiolytic-like effect of cannabidiol in the rat Vogel conflict test. Prog. Neuropsychopharmacol. Biol. Psychiatry 2006, 30, 1466-1471. [CrossRef] [PubMed]

118. Campos, A.C.; Guimarães, F.S. Involvement of 5HT1A receptors in the anxiolytic-like effects of cannabidiol injected into the dorsolateral periaqueductal gray of rats. Psychopharmacology 2008, 199, 223-230. [CrossRef] [PubMed]

119. American Psychiatric Association. Diagnostic and Statistical Manual of Mental Disorders, 5th ed.; American Psychiatric Publishing, Inc.: Arlington, VA, USA, 2013; ISBN 978-0-89042-555-8.

120. Han, M.-H.; Nestler, E.J. Neural substrates of depression and resilience. Neurother. J. Am. Soc. Exp. Neurother. 2017, 14, 677-686. [CrossRef] [PubMed]

121. Hardeveld, F.; Spijker, J.; De Graaf, R.; Hendriks, S.M.; Licht, C.M.M.; Nolen, W.A.; Penninx, B.W.J.H.; Beekman, A.T.F. Recurrence of major depressive disorder across different treatment settings: Results from the NESDA study. J. Affect. Disord. 2013, 147, 225-231. [CrossRef] [PubMed]

122. Smaga, I.; Bystrowska, B.; Gawliński, D.; Przegaliński, E.; Filip, M. The endocannabinoid/endovanilloid system and depression. Curr. Neuropharmacol. 2014, 12, 462-474. [CrossRef] [PubMed]

123. Hill, M.N.; Miller, G.E.; Ho, W.-S.V.; Gorzalka, B.B.; Hillard, C.J. Serum endocannabinoid content is altered in females with depressive disorders: A preliminary report. Pharmacopsychiatry 2008, 41, 48-53. [CrossRef] [PubMed]

124. Hill, M.N.; Miller, G.E.; Carrier, E.J.; Gorzalka, B.B.; Hillard, C.J. Circulating endocannabinoids and N-acyl ethanolamines are differentially regulated in major depression and following exposure to social stress. Psychoneuroendocrinology 2009, 34, 1257-1262. [CrossRef] [PubMed]

125. Hungund, B.L.; Vinod, K.Y.; Kassir, S.A.; Basavarajappa, B.S.; Yalamanchili, R.; Cooper, T.B.; Mann, J.J.; Arango, V. Upregulation of CB1 receptors and agonist-stimulated $\left[{ }^{35} \mathrm{~S}\right] \mathrm{GTP} \gamma \mathrm{S}$ binding in the prefrontal cortex of depressed suicide victims. Mol. Psychiatry 2004, 9, 184-190. [CrossRef] [PubMed]

126. Choi, K.; Le, T.; McGuire, J.; Xing, G.; Zhang, L.; Li, H.; Parker, C.C.; Johnson, L.R.; Ursano, R.J. Expression pattern of the cannabinoid receptor genes in the frontal cortex of mood disorder patients and mice selectively bred for high and low fear. J. Psychiatr. Res. 2012, 46, 882-889. [CrossRef] [PubMed]

127. Juhasz, G.; Chase, D.; Pegg, E.; Downey, D.; Toth, Z.G.; Stones, K.; Platt, H.; Mekli, K.; Payton, A.; Elliott, R.; et al. CNR1 gene is associated with high neuroticism and low agreeableness and interacts with recent negative life events to predict current depressive symptoms. Neuropsychopharmacology 2009, 34, 2019-2027. [CrossRef] [PubMed]

128. Domschke, K.; Dannlowski, U.; Ohrmann, P.; Lawford, B.; Bauer, J.; Kugel, H.; Heindel, W.; Young, R.; Morris, P.; Arolt, V.; et al. Cannabinoid receptor 1 (CNR1) gene: Impact on antidepressant treatment response and emotion processing in major depression. Eur. Neuropsychopharmacol. J. Eur. Coll. Neuropsychopharmacol. 2008, 18, 751-759. [CrossRef] [PubMed]

129. Monteleone, P.; Bifulco, M.; Maina, G.; Tortorella, A.; Gazzerro, P.; Proto, M.C.; Di Filippo, C.; Monteleone, F.; Canestrelli, B.; Buonerba, G.; et al. Investigation of CNR1 and FAAH endocannabinoid gene polymorphisms in bipolar disorder and major depression. Pharmacol. Res. 2010, 61, 400-404. [CrossRef] [PubMed]

130. Mitjans, M.; Serretti, A.; Fabbri, C.; Gastó, C.; Catalán, R.; Fañanás, L.; Arias, B. Screening genetic variability at the CNR1 gene in both major depression etiology and clinical response to citalopram treatment. Psychopharmacology 2013, 227, 509-519. [CrossRef] [PubMed]

131. Grinspoon, L.; Bakalar, J.B. The use of cannabis as a mood stabilizer in bipolar disorder: Anecdotal evidence and the need for clinical research. J. Psychoactive Drugs 1998, 30, 171-177. [CrossRef] [PubMed]

132. Ashton, C.H.; Moore, P.B.; Gallagher, P.; Young, A.H. Cannabinoids in bipolar affective disorder: A review and discussion of their therapeutic potential. J. Psychopharmacol. 2005, 19, 293-300. [CrossRef] [PubMed] 
133. Gruber, A.J.; Pope, H.G.; Brown, M.E. Do patients use marijuana as an antidepressant? Depression 1996, 4, 77-80. [CrossRef]

134. Denson, T.F.; Earleywine, M. Decreased depression in marijuana users. Addict. Behav. 2006, 31, 738-742. [CrossRef] [PubMed]

135. Babson, K.A.; Boden, M.T.; Bonn-Miller, M.O. Sleep quality moderates the relation between depression symptoms and problematic cannabis use among medical cannabis users. Am. J. Drug Alcohol Abuse 2013, 39, 211-216. [CrossRef] [PubMed]

136. Walsh, Z.; Gonzalez, R.; Crosby, K.; Thiessen, M.S.; Carroll, C.; Bonn-Miller, M.O. Medical cannabis and mental health: A guided systematic review. Clin. Psychol. Rev. 2017, 51, 15-29. [CrossRef] [PubMed]

137. Gruber, S.A.; Sagar, K.A.; Dahlgren, M.K.; Olson, D.P.; Centorrino, F.; Lukas, S.E. Marijuana impacts mood in bipolar disorder: A pilot study. Ment. Health Subst. Use 2012, 5, 228-239. [CrossRef]

138. Ringen, P.A.; Vaskinn, A.; Sundet, K.; Engh, J.A.; Jónsdóttir, H.; Simonsen, C.; Friis, S.; Opjordsmoen, S.; Melle, I.; Andreassen, O.A. Opposite relationships between cannabis use and neurocognitive functioning in bipolar disorder and schizophrenia. Psychol. Med. 2010, 40, 1337-1347. [CrossRef] [PubMed]

139. Braga, R.J.; Burdick, K.E.; DeRosse, P.; Malhotra, A.K. Cognitive and clinical outcomes associated with cannabis use in patients with bipolar I disorder. Psychiatry Res. 2012, 200, 242-245. [CrossRef] [PubMed]

140. Lev-Ran, S.; Roerecke, M.; Le Foll, B.; George, T.P.; McKenzie, K.; Rehm, J. The association between cannabis use and depression: A systematic review and meta-analysis of longitudinal studies. Psychol. Med. 2014, 44, 797-810. [CrossRef] [PubMed]

141. Aspis, I.; Feingold, D.; Weiser, M.; Rehm, J.; Shoval, G.; Lev-Ran, S. Cannabis use and mental health-related quality of life among individuals with depressive disorders. Psychiatry Res. 2015, 230, 341-349. [CrossRef] [PubMed]

142. Gibbs, M.; Winsper, C.; Marwaha, S.; Gilbert, E.; Broome, M.; Singh, S.P. Cannabis use and mania symptoms: A systematic review and meta-analysis. J. Affect. Disord. 2015, 171, 39-47. [CrossRef] [PubMed]

143. Parolaro, D.; Realini, N.; Vigano, D.; Guidali, C.; Rubino, T. The endocannabinoid system and psychiatric disorders. Exp. Neurol. 2010, 224, 3-14. [CrossRef] [PubMed]

144. Hill, M.N.; Patel, S.; Carrier, E.J.; Rademacher, D.J.; Ormerod, B.K.; Hillard, C.J.; Gorzalka, B.B. Downregulation of endocannabinoid signaling in the hippocampus following chronic unpredictable stress. Neuropsychopharmacology 2005, 30, 508-515. [CrossRef] [PubMed]

145. Hill, M.N.; Carrier, E.J.; McLaughlin, R.J.; Morrish, A.C.; Meier, S.E.; Hillard, C.J.; Gorzalka, B.B. Regional alterations in the endocannabinoid system in an animal model of depression: Effects of concurrent antidepressant treatment. J. Neurochem. 2008, 106, 2322-2336. [CrossRef] [PubMed]

146. Bortolato, M.; Mangieri, R.A.; Fu, J.; Kim, J.H.; Arguello, O.; Duranti, A.; Tontini, A.; Mor, M.; Tarzia, G.; Piomelli, D. Antidepressant-like activity of the fatty acid amide hydrolase inhibitor URB597 in a rat model of chronic mild stress. Biol. Psychiatry 2007, 62, 1103-1110. [CrossRef] [PubMed]

147. Hill, M.N.; Ho, W.-S.V.; Hillard, C.J.; Gorzalka, B.B. Differential effects of the antidepressants tranylcypromine and fluoxetine on limbic cannabinoid receptor binding and endocannabinoid contents. J. Neural Transm. 2008, 115, 1673-1679. [CrossRef] [PubMed]

148. Egashira, N.; Matsuda, T.; Koushi, E.; Higashihara, F.; Mishima, K.; Chidori, S.; Hasebe, N.; Iwasaki, K.; Nishimura, R.; Oishi, R.; et al. $\Delta$ 9-tetrahydrocannabinol prolongs the immobility time in the mouse forced swim test: Involvement of cannabinoid CB1 receptor and serotonergic system. Eur. J. Pharmacol. 2008, 589, 117-121. [CrossRef] [PubMed]

149. El-Alfy, A.T.; Ivey, K.; Robinson, K.; Ahmed, S.; Radwan, M.; Slade, D.; Khan, I.; ElSohly, M.; Ross, S. Antidepressant-like effect of $\Delta$ 9-tetrahydrocannabinol and other cannabinoids isolated from Cannabis sativa $\mathrm{L}$. Pharmacol. Biochem. Behav. 2010, 95, 434-442. [CrossRef] [PubMed]

150. Sartim, A.G.; Guimarães, F.S.; Joca, S.R.L. Antidepressant-like effect of cannabidiol injection into the ventral medial prefrontal cortex-Possible involvement of 5-HT1A and CB1 receptors. Behav. Brain Res. 2016, 303, 218-227. [CrossRef] [PubMed]

151. Di Forti, M.; Morgan, C.; Dazzan, P.; Pariante, C.; Mondelli, V.; Marques, T.R.; Handley, R.; Luzi, S.; Russo, M.; Paparelli, A.; et al. High-potency cannabis and the risk of psychosis. Br. J. Psychiatry 2009, 195, 488-491. [CrossRef] [PubMed] 
152. Schubart, C.D.; Sommer, I.E.; van Gastel, W.A.; Goetgebuer, R.L.; Kahn, R.S.; Boks, M.P. Cannabis with high cannabidiol content is associated with fewer psychotic experiences. Schizophr. Res. 2011, 130, $216-221$. [CrossRef] [PubMed]

153. Morgan, C.J.; Curran, H.V. Eff ects of cannabidiol on schizophrenia like symptoms in people who use cannabis. Br. J. Psychiatry 2008, 192, 306-307. [CrossRef] [PubMed] 